\title{
Validation of Soil Test and Yield Target based Fertilizer Prescription Model for Rice on Inceptisol of Eastern Zone of Uttar Pradesh, India
}

\author{
Manish Singh $^{1}$, Y.V. Singh ${ }^{1}$, S.K. Singh ${ }^{1}$, Pradip Dey ${ }^{2}$, L.K. Jat ${ }^{1}$ and R.L. Ram ${ }^{3}$ \\ ${ }^{1}$ AICRP on STCR, Department of Soil Science and Agricultural Chemistry, \\ Institute of Agricultural Sciences, Banaras Hindu University, Varanasi 221005 (U.P), India \\ ${ }^{2}$ Project coordinator STCR (AICRP), Indian Institute of Soil science Bhopal 462038 (M.P), India \\ ${ }^{3}$ Regional Sericultural Research Station, Central Silk Board, Kalimpong-734 301, \\ Darjeeling District, West Bengal, India \\ *Corresponding author
}

\section{Keywords}

Fertilizer prescription, STCR-INM, Rice, Soil fertility and yield target etc.

Article Info

Accepted:

15 January 2017

Available Online:

10 February 2017
On the basis of soil test value of farmer field, fertilizer prescription equations are essential to demonstrate the effectiveness of technology delivery to the stake holders in need. The present study was conducted at Bhojpur to evaluate the model through field experiments in Eastern zone of Uttar-Pradesh. The treatments included control, general recommendation dose, farmer practice, soil test crop response STCR based fertilizer dose for an yield target of 4.5 and $5.0 \mathrm{t} \mathrm{ha}^{-1}$. Based on the initial soil test values of available $\mathrm{N}, \mathrm{P}$ and $\mathrm{K}$ and the quantities of $\mathrm{N}, \mathrm{P}$ and $\mathrm{K}$ contributed through farm yard manure (FYM), fertilizer doses were calculated and applied for STCR and STCR-INM treatments for the respective yield targets. The treatments were imposed and cultivation practices were carried out periodically and the grain yield was recorded at harvest. Using the data on grain yield and fertilizer doses applied, benefit: cost ratio was worked out. The results of the experiments indicated that in the entire three farmer's field, the per cent achievement of the targeted yield was within $\pm 5 \%$ variation proving the validity of the equations for prescribing integrated fertilizer doses for rice. The highest mean per cent achievement was recorded in the yield target of $4.5 \mathrm{t} \mathrm{ha}^{-1}(99.96 \%)$ followed by $\mathrm{T}_{5}$ (yield target of $\left.5.0 \mathrm{t} \mathrm{ha}^{-1}\right)(98.36 \%$ ). The highest mean average yield was recorded in $\mathrm{T}_{5}$ STCR-NPK+FYM $5.0 \mathrm{t} \mathrm{ha}^{-1}(4918 \mathrm{~kg}$ $\mathrm{ha}^{-1}$ ) recording an increase of $30.93 \%$ over farmer's practice. The highest benefit: cost ratio (3.32) was also recorded in STCR-INM $\left(\mathrm{T}_{5}\right)$. The post-harvest soil available N, P and $\mathrm{K}$ indicated the build up and maintenance of soil fertility due to validation of soil test and yield target based fertilizer recommendation under STCR-INM. The fertilizer prescription equations developed for rice under STCR-INM can be recommended for Alluvial soil of Pratapgarh, Uttar-Pradesh (Inceptisol) for achieving a yield target of 4.5 and $5.0 \mathrm{t} \mathrm{ha}^{-1}$ with sustained soil fertility and it can be extrapolated to other agro-climatic zones of Uttar Pradesh on similar and allied soil types.

\section{Introduction}

Rice is an important staple food that provides $60-70 \%$ of body calorie intake of the consumers (Barah and Pandey, 2005). To assess food security in rice consuming country of the world, rice production should be increased by $50 \%$ in this country by 2025 . This additional rice will have to be produced on less land with less water, less labour and 
chemical (Zheng et al., 2004). Similarly, to achieve the projected targets of 680 and 711 million tons by 2015 and 2030, respectively, the productivity of rice has to be increased through the addition of suitable integrated approaches. Rice is grown in almost all the states of the country. West Bengal, Utter Pradesh, Madhya Pradesh, Bihar, Orissa, Andhra Pradesh, Assam, Tamilnadu, Punjab, Maharashtra and Karnataka are major rice growing states and contribute to a total $92 \%$ of area and production. India is still amongst the countries with the lowest rice yields. Seventy $(70 \%)$ of the 414 rice-growing districts report yields lower than the national average, clearly indicating that well after the advent of the high yield technology, a sizable area is categorized as low producing. $60 \%$ of the low productivity areas are in Bihar, Orissa, Assam, West Bengal and Utter Pradesh. Surprisingly, 32\% of the irrigated rice areas produce low yields (Tiwari, 2012). Rice based cropping systems are the major production systems contributing to food production. Current crop production systems are characterized by inadequate and imbalanced uses of fertilizers e.g. blanket fertilizer recommendations over large domains with least regard to the variability in soil fertility and productivity. Future gains in productivity and input use efficiency require soil and crop management technologies that are tailored to specific characteristics of individual farms or fields. Farm research demonstrated existence of large field variability in terms of soil nutrient supply, nutrient use efficiency, crop response etc. Management of this variability is a principle challenge for further increasing crop productivity of intensive rice crop systems (Rao, 2011).

Fertilizer is one of the costliest inputs in agriculture and the use of the right amount of fertilizer is fundamental for farm profitability and environmental protection (Kimetu et al.,
2004). Fertilizer consumption in India was 89.8 thousand tons in 1950-51 which has become $25.53 \mathrm{mt}$ in 2012-2013 (Agricultural Statistics at a Glance, 2014) in future the problem will aggravate as more grain has to be produced dew to continuously increasing population. Therefore, the application of of nutrients needs to be increased to keep the soil fertile. To sustain high yield, soil must have adequate supply of nutrients. Due to continuous intensive cultivation and use of high nutrients demands, the nutrient supplying capacity of soil is becoming a limited factor. This declining factor productivity is largely due to imbalanced fertilization along with fertilizer cost growing up. This needs to be supplied very carefully to maintain the soil fertility and obtain maximum yield. Soil testing as a tool for judicious fertilizer use is well recognized practices all over the world which take care of too little, too much or disproportionate application of nutrients. Fertilizer recommendation for preset yield target is refined technique particularly applicable under condition of fertilizer resources constraint for most efficient use of fertilizer and soil nutrients (Ramamoorthy and Velayutham, 1971). In this technique, the fertilizer are recommended separately for different field separately for different field separately on the basis of soil-test and are preset uniform targets yield depending upon the availability of fertilizer inputs.

Soil test based fertilizer prescription eliminates over or under usage of fertilizer inputs there by increasing the fertilizer use efficiency and yield of crops. Soil testing becomes one of the vital tools in increasing the yield of crops by optimum prescription of fertilizers to crops and maintenance of soil fertility. Targeted yield approach was first developed by Trung (1960) and Ramomoorthy et al., (1967) established theoretical basis and experimental technique 
to suit the Indian condition. Soil test based application of plant nutrients helps to realize higher response ratio and benefit: cost ratio as the nutrients are applied in proportion to the magnitude of the deficiency of a particular nutrient and the correction of the nutrients imbalance in soil helps to harness the synergistic effects of balanced fertilization (Rao and Srivastava, 2000). Hence, the present study was carried out for rice on Inceptisols of Pratapgarh, (U.P.) which neutral to slightly acidic in nature. Extrapolation of the results emanated from the study is possible if it is test verified at farmer's holdings. Therefore, to enhance the production of rice and to sustain soil health, development and verification of suitable fertilizer prescription model is highly essential.

\section{Materials and Methods}

To validate the fertilizer prescription equations developed for rice under for verification STCR equations for rice involved field experiments carried out at Bhojpur village of district Pratapgarh, (U.P.) during, 2014-15 at three sites followed by laboratory analysis of the soil and plants samples at the Department of Soil Science and Agricultural Chemistry, Institute of Agricultural Sciences, Banaras Hindu University, Varanasi.

Initial soil samples were collected from every farmer's field and analyzed for soil texture was determined by international pipette method (Piper, 1966), and $\mathrm{pH}$ in soil samples were measured with Beckman glass electrode in (1:2): soil: water suspension. Electrical conductivity in (1:2): soil: water suspension was determined in saturation extracts with digital EC meter (Richards, 1954). The soil samples were analysed for organic carbon by the method of Walkley and Black (1934), alkaline $\mathrm{KMnO}_{4}-\mathrm{N}$ (Subbiah and Asija, 1956), Olsen-P (Olsen et al., 1954), $\mathrm{NH}_{4} \mathrm{OAc}$ -
K flame photometric method (Jackson, 1973). The initial soil test value of different farmer's field is given in table 1. Fertilizer prescription equations for rice developed by Singh et al., (2014) on inseptisol of Varanasi at Institute of Agriculture Science, Banaras Hindu University under STCR approach are given below:

$\mathrm{FN}=4.76 \mathrm{~T}-0.49 \mathrm{SN}-0.34 \mathrm{M}-\mathrm{N}$

$\mathrm{FP}_{2} \mathrm{O}_{5}=1.53 \mathrm{~T}-1.41 \mathrm{SP}-0.09 \mathrm{M}-\mathrm{P}$

$\mathrm{FK}_{2} \mathrm{O}=2.92 \mathrm{~T}-0.35 \mathrm{SK}-0.11 \mathrm{M}-\mathrm{K}$

Where, $\mathrm{FN}, \mathrm{FP}_{2} \mathrm{O}_{5}$ and $\mathrm{FK}_{2} \mathrm{O}$ are fertilizer $\mathrm{N}$, $\mathrm{P}_{2} \mathrm{O}_{5}$ and $\mathrm{K}_{2} \mathrm{O}$ in $\mathrm{kg} \mathrm{ha}^{-1}$, respectively $\mathrm{T}=$ targeted grain yield in $\mathrm{q} \mathrm{ha}^{-1}, \mathrm{SN}, \mathrm{SP}$ and $\mathrm{SK}$ are available $\mathrm{N}, \mathrm{P}$ and $\mathrm{K}$ in $\mathrm{kg} \mathrm{ha}{ }^{-1}$ respectively $\mathrm{M}-\mathrm{N}, \mathrm{M}-\mathrm{P}$ and $\mathrm{M}-\mathrm{K}$ are $\mathrm{N}, \mathrm{P}$ and $\mathrm{K}$ supplied through the FYM in $\mathrm{kg} \mathrm{ha}^{-1}$. The treatments imposed were as follows:

$\mathrm{T}_{1}$ : Control

$\mathrm{T}_{2}$ : Farmer practice

$\mathrm{T}_{3}$ : General recommended dose

$\mathrm{T}_{4}$ : NPK application based on soil test crop response (STCR) equation and at 5 tone FYM (Target yield $4.5 \mathrm{t} \mathrm{ha}^{-1}$ )

$\mathrm{T}_{5}$ : NPK application based on soil test crop response (STCR) equation and at 5 tone FYM (Target yield $5.0 \mathrm{t} \mathrm{ha}^{-1}$ )

Based on the initial soil samples values of available $\mathrm{N}, \mathrm{P}_{2} \mathrm{O}_{5}$ and $\mathrm{K}_{2} \mathrm{O}$ and the some amount of $\mathrm{N}, \mathrm{P}$ and $\mathrm{K}$ supplied from the FYM, fertilizer doses were calculated applied for STCR treatments for various target yields. In the treatment $T_{2}$ and $T_{3}$ applied only inorganic fertilizers based on STCR equations developed, While treatments $\mathrm{T}_{4}$ and $\mathrm{T}_{5}$ received inorganic + FYM at $5 \mathrm{tha}^{-1}$ and NPK fertilizers supplied through FYM on STCR equations (Table 2) half dose of $\mathrm{N}$ and full dose of $\mathrm{P}_{2} \mathrm{O}_{5}$ and $\mathrm{K}_{2} \mathrm{O}$ were applied and half dose of $\mathrm{N}$ applied in two splits. $\mathrm{B}$ : $\mathrm{C}$ ratio was 
worked out based on the price of the produce crop yield in local market. Statistical analysis was carried out the finding data of each farmer's field as one replication randomly with randomized block design. Post harvest soil sample collected from each farmer's field and soil organic carbon and analyzed for available $\mathrm{N}, \mathrm{P}$ and $\mathrm{K}$ status.

\section{Results and Discussion}

\section{Grain yield}

The mean grain yield of the three farmers field revealed that the highest grain yield was founding in the treatment $\mathrm{T}_{5}$ (NPK respectively $T_{4}>T_{3}>T_{2}>T_{1}$. The treatment $T_{5}$ is obtained higher mean grain yield at all the farmers' field and followed by $\mathrm{T}_{4}$. In general soil test crop response (STCR) technology treatments recorded higher grain yield followed by general recommended dose, farmer practice and control (Table 2). The grain yield and straw yield were found increasing trend to that of the ascending treatments over $T_{1}$. The treatment $T_{1}$ is regarded lowest yield (17.00, 17.60 and 18.00 $\mathrm{q} \mathrm{ha}{ }^{-1}$ ) at all three farmers field as compare to STCR fertilizers treatments. Statistical scrutiny of data from the three farmers field revealed that STCR treatments gets high yield $\pm 5 \%$ from targeted yield in $\mathrm{T}_{4}$ and $\mathrm{T}_{5}$ (4.5 and $\left.5.0 \mathrm{t} \mathrm{ha}^{-1}\right)$. In the experiment of Farmer I, the actual yield obtained was around $\pm 5 \%$ from targeted yield. The integrated use of fertilizer and organic manure on the basis of soil test value produce significantly higher yield as compared to blanket application. Combination of organic manure and chemical fertilizers would be quite promising not only in providing greater stability in production, but also in maintaining better soil fertility. The increase yield was due to higher magnitude of yield components viz., increase number and size of spikelets, individual grain weight etc. These finding clearly indicated that the highest crop responses in term of yield was founded with the application of sub-optimal dose of NPK and farm yard manure and it was superior than other treatment. Thus, the balanced use of fertilizer either alone or in combination with FYM is necessary for sustaining soil fertility and productivity of crop. Shah and Kumar (2014) also reported that integrated nutrient management showed significant influence on productivity of hybrid rice.

\section{Economics/benefit cost ratio}

The yield reported from treatment $\mathrm{T}_{5}$ and $\mathrm{T}_{4}$ was $49.27 \mathrm{q} \mathrm{ha}^{-1}$ and $44.80 \mathrm{q} \mathrm{ha}^{1}$ with benefit: cost ratio 3.41 and 3.34 , respectively that are much higher than farmer's practice (2.37) in presented in table 3 , due to higher average yield. The fertilizer recommendation for former practices is $100 \mathrm{~N}: 35 \mathrm{P}: 35 \mathrm{~K}-\mathrm{kg} \mathrm{ha}^{-1}$ and for $50 \mathrm{q} \mathrm{ha}^{-1}$ and $45 \mathrm{q} \mathrm{ha}^{-1}$ target yield treatment recommendation on the basis of soil test value is $143 \mathrm{~N}$ : $53 \mathrm{P}: 79 \mathrm{~K} \mathrm{~kg} \mathrm{ha}^{-1}+5$ ton FYM and $119 \mathrm{~N}$ : $45 \mathrm{P}: 64 \mathrm{~K} \mathrm{~kg} \mathrm{ha}^{-1}+5$ ton FYM, respectively.

The Farmer II $48.57 \mathrm{q} \mathrm{ha}^{-1}$ yield obtained from targeted yield of $50 \mathrm{q} \mathrm{ha}^{-1}$ with higher benefit: cost ratio (3.24) as compare to farmer's practice (2.31) and General recommendation dose (2.36). The fertilizer recommendation for farmer practices is 110 $\mathrm{N}: 35 \mathrm{P}: 35 \mathrm{~K}-\mathrm{kg} \mathrm{ha}^{-1}$ and for $50 \mathrm{q} \mathrm{ha}^{-1}$ target yield treatment recommended on the basis of soil test value is $143 \mathrm{~N}$ : $60 \mathrm{P}: 79 \mathrm{~K} \mathrm{~kg} \mathrm{ha}^{-1}+5$ ton FYM. In the experiment of Farmer III, the yield obtained from targeted yield $50 \mathrm{q} \mathrm{ha}^{-1}$ of was higher (49.70 q $\mathrm{ha}^{-1}$ ) than farmer's practice (2.39) with benefit: cost ratio 3.32 with application of $133 \mathrm{~N}: 60 \mathrm{P}: 79 \mathrm{~K} \mathrm{~kg} \mathrm{ha}^{-1}$ +5 ton FYM. In other words treatment of targeted yield $50 \mathrm{q} \mathrm{ha}^{-1}$ found most economic treatment as compare to farmer practices and general recommendation. Similar results were also reported by Singh et al., (2015). The 
similar study was conducted in district Swat during 2007 to make comparative cost benefit analysis of per acre rice production of different rice varieties. For comparison, Cost Benefit Analysis approach was used. The total per acre rice production of these varieties was amounted to Rs. 40000, 52500, 33600, 30400 and 68750, respectively. The Benefit Cost Ratio of amounted was 2.24, 3.20, 1.80, 1.80 and 1.46. Similar results are also viewed by Sellamuthu et al., (2015).

Post harvest soil pH, EC and organic carbon

In general the $\mathrm{pH}$ of soil slightly decreases from initial mean value (6.8) at all three sites. The $\mathrm{pH}$ of soil of all three locations ranged between 6.63 and 6.80 (Table 4), it was slightly decrease in treated plots but not changed in control plots. The lowest soil $\mathrm{pH}$ value was observed in treatment $\mathrm{T}_{5}$ in all experimental sites. The highest soil $\mathrm{pH}$ value was recorded in treatment $\mathrm{T}_{1}$ (control). This may be due to the fact that the application of higher amount of nitrogenous fertilizer (urea) for obtaining higher targeted yield. Hydrolysis of urea in soil reduces soil $\mathrm{pH}$ and application of farm yard manure increases microbial activity in soil, microbes releases organic acids during decomposition of organic matter, it was also decrease soil $\mathrm{pH}$. The overall treatment effect was found to be non significant.

Table.1 Initial soil fertility status of the field experiments of various farmers

\begin{tabular}{clccccccccc}
\hline $\begin{array}{c}\text { S. } \\
\text { No. }\end{array}$ & Farmer & $\begin{array}{c}\text { Sand } \\
(\boldsymbol{\%})\end{array}$ & $\begin{array}{c}\text { Silt } \\
(\boldsymbol{\%})\end{array}$ & $\begin{array}{c}\text { Clay } \\
(\boldsymbol{\%})\end{array}$ & $\mathbf{p H}$ & $\begin{array}{c}\mathbf{E C} \\
\left(\mathbf{d S m}^{-\mathbf{1}}\right)\end{array}$ & $\begin{array}{c}\mathbf{O C} \\
(\boldsymbol{\%})\end{array}$ & $\begin{array}{c}\mathbf{K M n O}_{\mathbf{4}}-\mathbf{N} \\
\left(\mathbf{k g ~ h a}^{-\mathbf{1}}\right)\end{array}$ & $\begin{array}{c}\text { Olsen's P } \\
\left(\mathbf{k g ~ h a}^{-\mathbf{1}}\right)\end{array}$ & $\begin{array}{c}\mathbf{N H}_{\mathbf{4}} \mathbf{O A c}- \\
\left.\mathbf{K}_{(\mathbf{k g ~ h a}} \mathbf{- 1}^{-1}\right)\end{array}$ \\
\hline 1. & Farmer I & 50.30 & 32.60 & 32.60 & 6.7 & 0.45 & 0.45 & 157 & 19 & 145 \\
2. & Farmer II & 53.32 & 28.26 & 28.46 & 6.9 & 0.63 & 0.35 & 170 & 17 & 132 \\
3. & Farmer III & 50.40 & 27.50 & 27.50 & 6.8 & 0.32 & 0.32 & 173 & 23 & 135 \\
\hline
\end{tabular}

Table.2 Fertilizer doses $\left(\mathrm{kg} \mathrm{ha}^{-1}\right)$ imposed in three farmers field locations based on fertilizer prescription equation

\begin{tabular}{|c|c|c|c|c|c|c|c|c|c|c|}
\hline \multirow{3}{*}{$\begin{array}{c}\text { S. } \\
\text { No. }\end{array}$} & \multirow{3}{*}{ Treatment } & \multicolumn{3}{|c|}{ Farmer I } & \multicolumn{3}{|c|}{ Farmer II } & \multicolumn{3}{|c|}{ Farmer III } \\
\hline & & $\mathbf{N}$ & $\mathbf{P}$ & $\mathbf{K}$ & $\mathbf{N}$ & \multirow{2}{*}{$\begin{array}{c}P \\
\text { Kgh } \\
\text { a-1 }\end{array}$} & $\mathbf{K}$ & $\mathbf{N}$ & $\mathbf{P}$ & $\mathbf{K}$ \\
\hline & & & & & & & & & & \\
\hline 1. & Control & 0 & 0 & 0 & 0 & 0 & 0 & 0 & 0 & 0 \\
\hline 2. & Farmer practice & 135 & 35 & 35 & 110 & 35 & 35 & 100 & 40 & 30 \\
\hline 3. & $\begin{array}{l}\text { General } \\
\text { recommendation dose }\end{array}$ & 120 & 55 & 55 & 140 & 75 & 70 & 135 & 70 & 65 \\
\hline 4. & Target yield 45 q/ha & 119 & 45 & $64(5)^{*}$ & 119 & 52 & $64(5)^{*}$ & 109 & 52 & $64(5)^{*}$ \\
\hline 5. & Target yield $50 \mathrm{q} / \mathrm{ha}$ & 143 & 53 & $79(5)^{*}$ & 143 & 60 & $79(5)^{*}$ & 133 & 60 & $79(5)^{*}$ \\
\hline
\end{tabular}

Note: The number indicated in bracket is FYM $\left(\mathrm{t} \mathrm{ha}^{-1}\right)$ 
Table.3 Economics of verification trails for rice crop of Bhojpur in Pratapgarh district

\begin{tabular}{|c|c|c|c|c|c|c|c|}
\hline Treatments & $\begin{array}{l}\text { Fertilizer dose } \\
\text { NPK }\left(\mathrm{kg} \mathrm{ha}^{-1}\right) \text { and } \\
\text { FYM }\left(\mathrm{t} \mathrm{ha}^{-1}\right)\end{array}$ & $\begin{array}{l}\text { Actual mean } \\
\text { yield }\left(\mathrm{kg} \mathrm{ha}^{-1}\right)\end{array}$ & $\begin{array}{c}\text { Additional } \\
\text { yield } \\
\left(\mathrm{kg} \mathrm{ha}^{-1}\right)\end{array}$ & $\begin{array}{l}\text { Value of } \\
\text { additional } \\
\text { yield (Rs.) }\end{array}$ & $\begin{array}{c}\text { Cost of } \\
\text { fertilizer (Rs.) }\end{array}$ & $\begin{array}{l}\text { Net benefit } \\
\text { (Rs.) }\end{array}$ & $\begin{array}{l}\mathrm{B} / \mathrm{C} \\
\text { ratio }\end{array}$ \\
\hline \multicolumn{8}{|c|}{ Farmer I: Name - Shri Ram Kinkar Singh, Village- Bhojpur } \\
\hline $\mathrm{T}_{1}$-Control & $0-0-0$ & 1760 & - & - & - & - & - \\
\hline $\mathrm{T}_{2}$-FP & $100-35-35$ & 2873 & 1113 & 15582 & 4627 & 10955 & 2.37 \\
\hline $\mathrm{T}_{3}$-GRD & $120-55-55$ & 3578 & 1827 & 25578 & 6625 & 18953 & 2.86 \\
\hline $\mathrm{T}_{4}-\mathrm{TY} 45 \mathrm{q} \mathrm{ha}^{-1}$ & $119-45-64 \& 5$ & 4480 & 2793 & 39102 & 8782 & 30320 & 3.34 \\
\hline $\mathrm{T}_{4^{-}} \mathrm{TY} 50 \mathrm{q} \mathrm{ha}^{-1}$ & $143-53-79 \& 5$ & 4927 & 1367 & 44338 & 10043 & 34295 & 3.41 \\
\hline \multicolumn{8}{|c|}{ Farmer II: Name - Shri Ram Pratap Singh, Village-Bhojpur } \\
\hline $\mathrm{T}_{1}$-Control & $0-0-0$ & 1700 & - & - & - & - & - \\
\hline $\mathrm{T}_{2}-\mathrm{FP}$ & $100-35-35$ & 2835 & 1135 & 15890 & 4801 & 11089 & 2.31 \\
\hline $\mathrm{T}_{3}-\mathrm{GRD}$ & $140-75-70$ & 3735 & 2035 & 28490 & 8492 & 19998 & 2.36 \\
\hline $\mathrm{T}_{4^{-}} \mathrm{TY} 45 \mathrm{q} \mathrm{ha}^{-1}$ & $119-52-64 \& 5$ & 4450 & 2825 & 39550 & 9175 & 30375 & 3.20 \\
\hline $\mathrm{T}_{4^{-}} \mathrm{TY} 50 \mathrm{q} \mathrm{ha}^{-1}$ & $143-60-79 \& 5$ & 4857 & 3157 & 44198 & 10436 & 33762 & 3.24 \\
\hline \multicolumn{8}{|c|}{$\begin{array}{l}\text { Farmer III: Name - Shri Chandra Pratap Singh, Village-Bhojpur } \\
\end{array}$} \\
\hline $\mathrm{T}_{1}$-Control & $0-0-0$ & 1800 & - & - & - & - & - \\
\hline $\mathrm{T}_{2}-\mathrm{FP}$ & $100-40-30$ & 2956 & 1156 & 16184 & 4777 & 11407 & 2.39 \\
\hline $\mathrm{T}_{3}-\mathrm{GRD}$ & $135-70-65$ & 3957 & 2157 & 30198 & 7992 & 22206 & 2.78 \\
\hline $\mathrm{T}_{4}-\mathrm{TY} 45 \mathrm{q} \mathrm{ha}^{-1}$ & $109-52-64 \& 5$ & 4566 & 2766 & 38724 & 9001 & 29723 & 3.30 \\
\hline $\mathrm{T}_{4}-\mathrm{TY} 50 \mathrm{q} \mathrm{ha}^{-1}$ & $133-60-79 \& 5$ & 4970 & 3170 & 44380 & 10262 & 34118 & 3.32 \\
\hline
\end{tabular}

Note: Paddy at Rs 14/kg, N at Rs 17.39/kg, $\mathrm{P}_{2} \mathrm{O}_{5}$ at Rs 56.25/kg, $\mathrm{K}_{2} \mathrm{O}$ at Rs 26.66/kg, FYM at Rs 0.5/kg

A miner modification was made in the ready reckoner, $\mathrm{T}_{1}$ control, $\mathrm{T}_{2} \mathrm{FP}$ : Farmers practice i.e. the fertilizer doses the farmers generally applied in the area, $\mathrm{T}_{3}$ GRD: General recommendation $\mathrm{T}_{4}$ and $\mathrm{T}_{5}$ STCR targeted yield 45 and $50 \mathrm{q}^{-1}$ of agricultural department of the district on the basis of soil test value, B: $\mathrm{C}$ ratio: benefit cost ratios. 
Table.4 Post harvest soil fertility by various treatments for rice crop of Bhojpur in Pratapgarh district

\begin{tabular}{|c|c|c|c|c|c|c|c|c|c|c|c|c|c|c|c|c|c|c|c|}
\hline \multirow{3}{*}{ S. No. } & \multirow{3}{*}{ Treatments } & \multicolumn{6}{|c|}{ Farmer I } & \multicolumn{6}{|c|}{ Farmer II } & \multicolumn{6}{|c|}{ Farmer III } \\
\hline & & \multirow[b]{2}{*}{$\mathrm{pH}$} & \multirow{2}{*}{$\begin{array}{l}\mathrm{EC} \\
(\mathrm{dS} \\
\left.\mathrm{m}^{-1}\right)\end{array}$} & \multirow[b]{2}{*}{$\begin{array}{l}\mathrm{OC} \\
(\%)\end{array}$} & $\mathrm{N}$ & $\mathrm{P}$ & $\mathrm{K}$ & \multirow[b]{2}{*}{$\mathrm{pH}$} & \multirow{2}{*}{$\begin{array}{l}\mathrm{EC} \\
(\mathrm{dS} \\
\left.\mathrm{m}^{-1}\right)\end{array}$} & \multirow[b]{2}{*}{$\begin{array}{l}\mathrm{OC} \\
(\%)\end{array}$} & $\mathrm{N}$ & $\mathrm{P}$ & \multirow[t]{2}{*}{$\mathrm{K}$} & \multirow[b]{2}{*}{$\mathrm{pH}$} & \multirow{2}{*}{$\begin{array}{l}\mathrm{EC} \\
(\mathrm{dS} \\
\left.\mathrm{m}^{-1}\right) \\
\end{array}$} & \multirow{2}{*}{$\begin{array}{l}\mathrm{OC} \\
(\%)\end{array}$} & $\mathrm{N}$ & & $\mathrm{K}$ \\
\hline & & & & & & $\left.\mathrm{kg} \mathrm{ha}^{-1}\right)$ & & & & & & $\left(\mathrm{kg} \mathrm{ha}^{-1}\right.$ & & & & & \multicolumn{3}{|c|}{$\left(\mathrm{kg} \mathrm{ha}^{-1}\right)$} \\
\hline 1 & Control & 6.80 & 0.20 & 0.40 & 160 & 20 & 140 & 6.75 & 0.25 & 0.33 & 157 & 19 & 135 & 6.78 & 0.24 & 0.31 & 165 & 20 & 145 \\
\hline 2 & $\begin{array}{l}\text { Farmer } \\
\text { practice }\end{array}$ & 6.70 & 0.23 & 0.45 & 163 & 22 & 145 & 6.70 & 0.26 & 0.35 & 162 & 22 & 145 & 6.70 & 0.28 & 0.35 & 170 & 22 & 155 \\
\hline 3 & GRD & 6.65 & 0.25 & 0.48 & 175 & 29.5 & 155 & 6.63 & 0.26 & 0.40 & 174 & 25 & 165 & 6.65 & 0.29 & 0.38 & 190 & 25 & 175 \\
\hline 4 & $\begin{array}{l}\text { STCR-Target } \\
\text { yield } \\
(45 \mathrm{q} / \mathrm{ha})\end{array}$ & 6.73 & 0.29 & 0.54 & 180 & 32 & 170 & 6.70 & 0.28 & 0.45 & 180 & 29.5 & 170 & 6.70 & 0.32 & 0.43 & 200 & 32 & 180 \\
\hline 5 & $\begin{array}{l}\text { STCR-Target } \\
\text { yield } \\
(50 \mathrm{q} / \mathrm{ha})\end{array}$ & 6.63 & 0.32 & 0.59 & 200 & 35 & 185 & 6.63 & 030 & 0.49 & 195 & 32 & 180 & 6.65 & 0.36 & 0.46 & $\begin{array}{c}211 . \\
3\end{array}$ & 38 & 195 \\
\hline & $\mathrm{SEm} \pm$ & 0.15 & 0.03 & 0.03 & 2.02 & 1.00 & 2.23 & 0.14 & 0.01 & 0.02 & $\begin{array}{c}1.1 \\
7\end{array}$ & 0.92 & 0.71 & 0.16 & 0.03 & 0.01 & 1.98 & 0.93 & 2.12 \\
\hline & $\mathrm{CD}$ at $5(\%)$ & 0.45 & 0.08 & 0.09 & 5.95 & 2.97 & 6.59 & 0.43 & 0.04 & 0.07 & $\begin{array}{c}3.4 \\
5\end{array}$ & 2.70 & 2.80 & 0.47 & 0.09 & 0.03 & 5.85 & 2.75 & 6.25 \\
\hline
\end{tabular}


The effect of treatments in EC found no significant but it increases slightly with increase doses of fertilizer from initial value $(0.45,0.63$ and 0.32$)$ in all three sites (Table 4). The electrical conductivity ranged between 0.20 to $0.36 \mathrm{dS} \mathrm{m}^{-1}$. The highest soil electrical conductivity was observed in treatment $\mathrm{T}_{5}$ in all soil samples collected from experiment conducted at farmer's field. The EC of soil is result of soluble salts present in soil at any particular temperature. The application of fertilizer and organic manure increases soluble salts in soil resulted electrical conductivity rises. The effect of treatments on soil organic carbon found significant and in it increase from initial values $(0.45,0.35$ and $0.32 \%)$ in all three sites. In experiments the data indicated that organic carbon of soil under various treatments ranges from 0.40 to $0.59,0.33$ to 0.49 and 0.31 to 0.46 in control and treatment $\mathrm{T}_{5}$ at farmer I, farmer II and farmer III, respectively (Table 4). In general all soil samples collected from experiment conducted at farmers field showed that the higher concentration of organic carbon were recorded in the treatment $T_{5}$ and lower value was recorded in the treatment $T_{1}$.

The organic carbon content of soil with minimum value of organic in $\mathrm{T}_{1}(0.40,0.33$ and 0.31) had increased significantly and attained maximum value in the treatment $\mathrm{T}_{5}$ at all farmer's plot. Fertilizer application further helped in increasing the organic carbon content, which is due to increased contribution from the biomass, as it is also observed that the fertilizer application increased the crop yield. Contribution from root stubble could also be expected to follow the same trend. Similar views were expressed by Thakur et al., (2011).

\section{Post Harvest Soil Available Nutrients}

The data on $\mathrm{KMnO}_{4}-\mathrm{N}$, Olsen-P and $\mathrm{NH}_{4} \mathrm{OAc}-\mathrm{K}$ indicated the build-up and maintenance of post harvest soil fertility due to soil test based fertilizer recommendation under INM. Despite higher removal of nutrients, the fertility status was maintained in STCR-INM as compared to the general recommendation and farmer practice given in (Table 4). This might be attributed to the prevention of losses of nutrients under INM, even after meeting the crop needs. Greater profit consistent with maintenance of soil fertility status was realized when fertilizer was applied for appropriate yield targets in succession over years using STCR-INM concept (Ramamoorthy and Velayutham, 2011). Application of FYM in conjunction with chemical fertilizers will not only increase the productivity of all the cropping sequences but also improve the soil fertility (Gupta and Jagannath, 1998). Santhi et al., (2011) established that soil-test-based fertilizer prescription for beet root was found to be useful in increasing yield and also maintained soil fertility.

From experiment we found that the highest targeted yield of STCR-INM treatment $\mathrm{T}_{5}$ and $\mathrm{T}_{4}$ all three farmers experimental field within $\pm 5 \%$ deviation certifying the validity of the equations for prescribing integrated fertilizer dose for rice. The post harvest soil available $\mathrm{N}, \mathrm{P}$ and $\mathrm{K}$ status indicated the build-up soil nutrients and maintain soil fertility due to soil test based fertilizer recommendation under STCR approach. Hence, the fertilizer prescription equation developed for rice under STCR-INM is recommended for Alluvial soils of Pratapgarh (U.P.) for getting yield target of 4.5 and $5.0 \mathrm{t} \mathrm{ha}^{-1}$ with sustained soil health.

It was concluded from the present investigation that the percent achievement of the targeted yield of all the three verification trials was within $\pm 5 \%$ variation proving the validity of the equations for prescribing integrated fertilizer doses for rice. The grain 
yield of rice from the three verification trials indicated that STCR-INM 45 and $50 \mathrm{q} \mathrm{ha}^{-1}$ (target yield) was found significantly higher grain yield over all other treatments, whereas farmer practice recorded significantly lower yield. Among the treatments, STCR-INM recorded relatively higher benefit: cost ratio and per cent achievement than other treatments. The post-harvest soil organic carbon and soil available $\mathrm{N}, \mathrm{P}$ and $\mathrm{K}$ status indicated the build-up and maintenance of soil fertility due to soil test based fertilizer recommendation under INM. Hence, the fertilizer prescription equations developed for rice under INM on Inceptisol can be recommended for Bhojpur village of the district Pratapgarh (U.P.) for achieving yield target of 4.5 and $5.0 \mathrm{t} \mathrm{ha}^{-1}$ with sustained soil health.

\section{Acknowledgements}

The authors are grateful to Dr. R.P. Singh, Director and Dr. B.R. Maurya, Head of Department of Soil Science and Agricultural Chemistry for taking their keen interest and encouragement to carry out the present research work.

\section{References}

Agricultural Statistics at a Glance. 2014. Government of India, Ministry of Agriculture and Cooperation, Directorate of economics and Statistics. pp-324-325.

Barah, B.C., and S. Pandey. 2005. Rainfed rice production system in Eastern India: An on farm diagnosis and policy alternative. Indian J. Agri. Economics, 60: 110-136.

Bouyoucos, G.T. 1962. Hydrometer method for measuring particle size analysis of soil. Agronomy J., 54: 464-465.

Gupta, A.P., and Jagannath. 1998. Role of farm yard manure in integrated plant nutrient supply system for sustainable agriculture. Bull. Indian Institute Soil Sci., 2: 73- 77.

Jacson, M.L. 1973. Soil Chemical Analysis: Prentice Hall of India Pvt. Ltd., New Delhi.

Kimetu, M., D.N. Mugendi., C.A. Palm, P.K. Mutro., C.N. Gachengo., S. Nandwa, and B. Kungu. 2004. African network on soil biology and fertility. pp-207224.

Olsen, S.R., C.V. Cole., F.S. Watnabe, and L. Dean. 1954. Estimation of available phosphorus in soil by extraction with sodium biocarbonate (USDA) Circular 939.

Piper, C.S. 1966. Soil and Plant Analysis. Hans Publishers, Bombay.

Ramamoorthy, B., R.L. Narasimham, and R.S. Dinesh. 1967. Fertilizer application for specific yield target of sonara-64 wheat. Indian Farming, 17(5): 43-45.

Ramamoorthy, B., and M. Velaytha. 2011. The Law of Optimum' and soil test based fertilizer use for targeted yield of crops and soil fertility management for Sustainable agriculture. Madras Agri. J., 98: 295-307.

Ramamoorthy, B., and M. Velagutham. 1971. Soil test crop response correlation work in India. World soil Resourse Report No, 41: 96-102.

Rao, K.V. 2011. Site-specific integrated nutrient management for sustainable rice production and growth. Rice Knowledge management portal (RKMP) Publication Directorate of Rice Research Rajendranagar, Hyderabad, pp. 1-71.

Rao, S., and S. Srivastava. 2000. Soil test based fertilizer use-a must for sustainable agriculture. Fertilizer News, 45: 25-38.

Richards, L.A. 1954. Diagnosis and improvement of saline and alkali soils. Agriculture Handbook 60, United States 
Department of Agriculture, Washington DC, USA, pp 104.

Santhi, R., S. Poongothai, and S. Maragatham. 2011. STCR-IPNS prescription for higher productivity of beetroot and sustained soil fertility. In: Proc. National Symposium on soil Health Improvement for Enhancing Crop Productivity, Tamilnadu Agriculture University, Coimbatore and AICRIP on soil test crop response correlation, Indian Institute of soil Sci., Bhopal, 17-18 march. Pp.75.

Sellamuthu, K.M., R. Santhi., S. Maragatham, and P. Dey. 2015. Validation of soil test and yield target based fertilizer prescription model for wheat on Inceptisol. Res. Crops, 16(1): 53-58.

Shah, R.A., and S. Kumar. 2014. Direct and residual effect of integrated nutrient management and economics in hybrid rice wheat cropping system. AmericanEurasian J. Agri. Environ. Sci., 14(5): 455-458.

Singh, Y.V., and S.K. Singh. 2014. Fertilizer prescription for targated yield of rice (Oryza sativa L. Var. Saryu-52) in an Inceptisol of Varanasi. Indian J. Ecol., 42(2): 282-285.

Singh, A.K., Gautam., U.S. Singh., A. Singh, and P. Shrivastava. 2015. Impact of nutrient management technologies in transplanted rice under irrigated domains of central India. African $J$. Agri., 10(5): 345-350.

Subba Rao, A., and S. Srivastava. (Eds.)
1999. Soil Test Based Fertilizer Recommendations for Targeted Yield of Crops. Proceedings of the National Seminar on Soil Testing for Balanced and Integrated Use of Fertilizers and Manures, Indian Institute of Soil Science, Bhopal.

Subbiah, B.V., and G.L. Asija. 1956. A Rapied procedure for estimation of available nitrogen in soil. Curr. Sci., 25: $259-60$.

Thakur, R.S.D., U.K. Vaishya, and M. Singh. 2011. Impact of continuous use of inorganic fertilizer and organic manure on soil properties and productivity under soybean-wheat intensive cropping of a vertisol. J. Indian Soc. Soil Sci., 59: $74-81$.

Tiwari, K.N. 2012. Rice Production and Nutrient Management in India. Better Crops Int., 16(Special Supplement): pp. 18-22.

Truog, M. 1960. Fifty years of soil testing. Transaction of the $7^{\text {th }}$ Int. Congress of Soil Sci., 3: 46-53.

Walkley, A., and C.A. Black. 1934. An examination of the Degtjareff method for determining soil organic matter and a proposed modification of the chromic acid titration method. Soil Sci., 37: 2938.

Zheng, J., X. Lu., X. Jiang, and Y. Tang. 2004. The system of rice intensification (SRI) for super high yields of rice in Sichuan Basin. $4^{\text {th }}$ Int. Crop Sci. Congress.

\section{How to cite this article:}

Manish Singh, Y.V. Singh, S.K. Singh, Pradip Dey, L.K. Jat and Ram, R.L. 2017. Validation of Soil Test and Yield Target based Fertilizer Prescription Model for Rice on Inceptisol of Eastern Zone of Uttar Pradesh. Int.J.Curr.Microbiol.App.Sci. 6(2): 406-415. doi: http://dx.doi.org/10.20546/ijcmas.2017.602.045 